\title{
Beyond the myths about work addiction: Toward a consensus on definition and trajectories for future studies on problematic overworking
}

\author{
A response to the commentaries on: Ten myths about work addiction \\ (Griffiths et al., 2018)
}

\author{
PAWEŁ A. ATROSZKO ${ }^{1 *}$, ZSOLT DEMETROVICS ${ }^{2}$ and MARK D. GRIFFITHS \\ ${ }^{1}$ Department of Psychometrics and Statistics, Institute of Psychology, University of Gdańsk, Gdańsk, Poland \\ ${ }^{2}$ Department of Clinical Psychology and Addiction, Institute of Psychology, ELTE Eötvös Loránd University, Budapest, Hungary \\ ${ }^{3}$ Psychology Department, Nottingham Trent University, Nottingham, UK
}

(Received: February 20, 2019; revised manuscript received: February 25, 2019; accepted: February 26, 2019)

\begin{abstract}
In an unprecedented collaborative effort to integrate the existing knowledge on work addiction and delineate trajectories for future studies, several papers from work addiction researchers (including some of the most prolific experts in the field) have contributed to the debate on the misconceptions/myths about this problematic behavior. On the basis of the overview of the presented arguments, the most commonly proposed recommendations were that there should be: (a) a general definition of work addiction, (b) the need for more transdisciplinary and integrative approach to research, and (c) propositions regarding more high-quality research. These three aspects are summarized in the present paper. There is a general agreement among work addiction researchers that work addiction is a problematic behavior that merits more systematic studies, which require input and expertise from a wide range of fields due to its complex nature.
\end{abstract}

Keywords: workaholism, work addiction, problematic overworking, problematic work, behavioral addiction

\section{INTRODUCTION}

In a collaborative effort to integrate the existing knowledge on work addiction and delineate trajectories for future studies, eight commentaries by 15 authors responded to our deliberately provocative debate paper (Griffiths, Demetrovics, \& Atroszko, 2018) concerning 10 proposed myths about work addiction (i.e., Andreassen, Schaufeli, \& Pallesen, 2018; Kun, 2018; Lior, Abira, \& Aviv, 2018; Loscalzo \& Giannini, 2018a; Malinowska, 2018; Quinones, 2018; Sussman, 2018; Tóth-Király, Bőthe, \& Orosz, 2018). The researchers participating in this debate are among authors with the highest number of papers on work addiction indexed in the Web of Science that were published during the past decade, and seven of these researchers wrote review papers on work addiction during that period (Andreassen, 2014; Andreassen \& Pallesen, 2016; Griffiths et al., 2018; Griffiths \& Karanika-Murray, 2012; Quinones \& Griffiths, 2015; Sussman, 2012). Consequently, the ensuing debate can arguably be considered to reflect the opinions of a fairly representative group of researchers who contribute some of the highest quality research in the field and who frequently review the existing literature. It is an unprecedented and highly appreciated endeavor in this area of research to attempt to jointly develop consensus regarding current status of work addiction as well as to provide diverse perspectives on crucial areas for further investigation.

In general, many important arguments were made on particular myths supported with extensive and diverse references, significantly contributing to broadening the perspectives on the issue and expressing the need for further clarification of particular questions. Nevertheless, there was a reasonably high level of consensus among the commenting researchers concerning the myths (Table 1). Most notably, none of the commentators had any doubts that the data gathered during few decades of research support the notion that work addiction is a problematic behavior, even though more high-quality data are needed to have a better understanding of its symptoms, etiology, epidemiology, course, treatment, and prognosis. Andreassen et al. $(2018$, p. 858) think that the field is still "in its infancy," which can be read as an expression of the most rigorous standards of scientific inquiry.

One of the inciting factors for this debate was misconceptions about work addiction research propagated in the addiction literature (Atroszko, 2019; Karderfelt-Winther et al., 2017, p. 1711; Starcevic, Billieux, \& Schimmenti, 2018, p. 920).

* Corresponding author: Asst. Prof. Paweł A. Atroszko; Department of Psychometrics and Statistics, Institute of Psychology, University of Gdańsk, Bazynskiego 4, 80-952, Gdańsk, Poland; Phone: +48 5852343 22; E-mail: p.atroszko@ug.edu.pl

This is an open-access article distributed under the terms of the Creative Commons Attribution-NonCommercial 4.0 International License, which permits unrestricted use, distribution, and reproduction in any medium for non-commercial purposes, provided the original author and source are credited, a link to the CC License is provided, and changes - if any - are indicated. 
Atroszko et al.

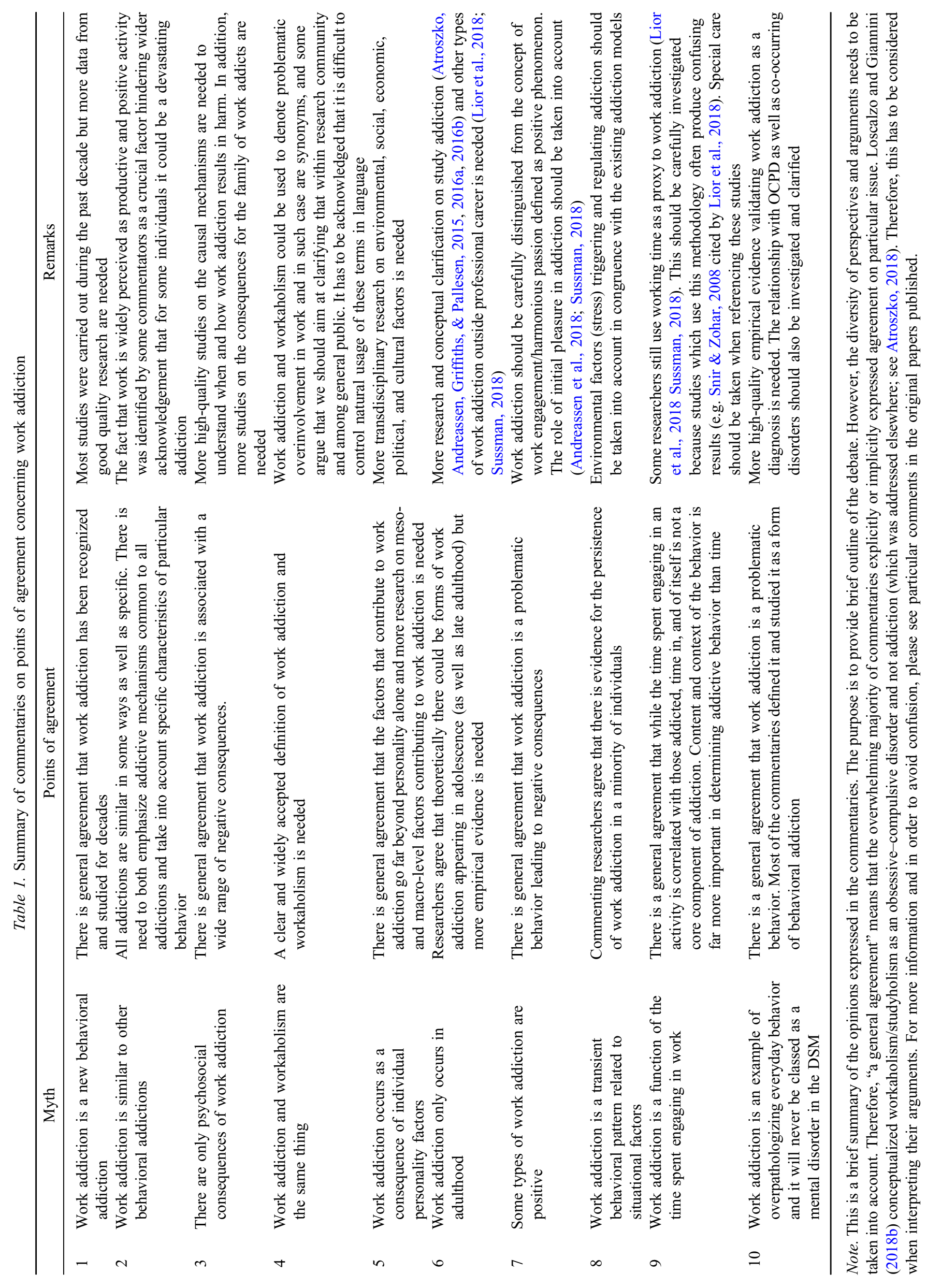


The caution of expression of the comments only supports the notion that some of the most impactful researchers investigating work addiction are cautious methodologically and conceptually not to overstate the implications of the known facts and compromise "the credibility of the field of addictive disorders" (Kardefelt-Winther et al., 2017, p. 1709). Among the most important challenges facing the field and most frequently mentioned in the commentaries to our original paper are: (a) the need for widely accepted definition of work addiction; (b) more transdisciplinary and integrative approach in research including micro-, meso-, and macro-level factors contributing to work addiction; and (c) more high-quality research going beyond cross-sectional self-report studies.

\section{DEFINITION OF WORK ADDICTION: CLINICAL FRAMEWORK INTEGRATED WITH ORGANIZATIONAL RESEARCH}

There is a need for a clinically based definition of work addiction and one that simultaneously considers transdisciplinary research, especially the integration of the data from work and organizational psychology research. Given that all the commentaries agreed that work addiction is a problematic behavior leading to clinically relevant negative consequences, it appears to be paramount that a definition of work addiction should be grounded within a clinical framework. It follows from the fact that most of the currently existing conceptualizations of work addiction (explicitly or implicitly) define it as a behavioral addiction (Andreassen \& Pallesen, 2016; Griffiths \& Karanika-Murray, 2012; Quinones \& Griffiths, 2015; Sussman, 2012) and the available data support such an assumption (Griffiths et al., 2018). Furthermore, the definition of work addiction should be congruent with the current developments concerning the criteria for conceptualizing a behavioral addiction (Karderfelt-Winther et al., 2017; Starcevic et al., 2018). In addition, because much of the existing research is being conducted within the organizational and work psychology framework, the definition should take into account developments on work addiction research in these fields, specifically different high work involvement frameworks (Snir \& Harpaz, 2012; Vallerand, 2015) and distinction between work addiction and work engagement (Griffiths et al., 2018).

Addiction is characterized by compulsivity (Everitt \& Robbins, 2005; Koob \& Volkow, 2010). A review by Sussman and Sussman (2011) identified elements common to most of the definitions of addictions. Since temporary satiation is possibly controversial, some researchers may argue that it should be omitted from a strict definition of addiction. If so, the other elements are congruent with most of the suggested and widely recognized definitions of a behavioral addiction to date (Grant, Potenza, Weinstein, \& Gorelick, 2010; Griffiths, 1996, 2005; Holden, 2001; Karderfelt-Winther et al., 2017). These elements are: (a) engagement in the behavior to achieve appetitive effects (e.g., pain reduction, affect enhancement, arousal manipulation, and/or fantasy), (b) total preoccupation with the behavior, (c) loss of control, and (d) suffering negative consequences. These elements are also to a large extent congruent with most of the existing definitions of work addiction, which include the elements of preoccupation with work/compulsion or addiction to work, and negative consequences of excessive work (Andreassen \& Pallesen, 2016; Fassel, 1992; Griffiths, 2011; Oates, 1971; Robinson, 2014, Schaufeli, Taris, \& Bakker, 2006; Spence \& Robbins, 1992; Taris, Schaufeli, \& Verhoeven, 2005; for a overview, see Andreassen, 2014; Griffiths \& Karanika-Murray, 2012; Sussman, 2012). Therefore, a tentative definition of work addiction is suggested along the following lines (with Part A being a general definition and complementary Part B being a more preliminary suggested specific definition):

\section{Part $A$}

Work addiction is characterized by a compulsion to work and preoccupation with work activities leading to a significant harm and distress of a functionally impairing nature to the individual and/or other significantly relevant relationships (friends and family). The behavior is characterized by the loss of control over the working activity and persists over a significant period of time. This problematic work-related behavior can have varying intensity from mild to severe.

\section{Part B}

Loss of control over the working activity involves working more than planned, despite the negative consequence and or unsuccessful attempts to reduce the activity and/or progressive increase in time spent on working. Withdrawal symptoms (including irritability, negative feelings, sleep problems, etc.) are frequent if the planned/desired amount of work is hindered or appear when attempts at reduction of the amount of work are undertaken. The work activity often serves to reduce negative feelings and/or avoid interpersonal and/or intrapersonal conflicts.

Although the distinction between work addiction and work engagement is currently fairly established (Andreassen, 2014; Andreassen \& Pallesen, 2016; Clark, Michel, Zhdanova, Pui, \& Baltes, 2016; Griffiths et al., 2018; Griffiths \& Karanika-Murray, 2012; KaranikaMurray, Duncan, Pontes, \& Griffiths, 2015; Quinones \& Griffiths, 2015; Sussman, 2012), there is still need to address the findings related to different levels of work enjoyment and work involvement among those working compulsively (Loscalzo \& Giannini, 2018a; Snir \& Harpaz, 2012; Spence \& Robbins, 1992). It appears that this could be explained to some extent by the stage of addiction or level of addiction, which somewhat parallels previously used classification of alcohol abuse and alcohol dependence (see Malinowska, 2018). In order to address the issue of different levels of problematic behavior, subclasses of mild, moderate, and severe work addiction could be used analogically to the currently used diagnostic criteria of alcohol-use disorder (American Psychiatric Association [APA], 2013). Advantages and disadvantages of this approach should be taken into account (Babor \& Caetano, 2008; Hasin, 2012; O’Brien, 2011; Wakefield, 2015).

When it comes to loss of control, which is fundamental to all addictions, special care needs to be taken in order to 
distinguish between the need for control executed in relation to performing work itself, which is characteristic of many work addicts, and the loss of control over the degree of involvement in work and significantly reduced ability to control other aspects of their day-to-day lives (see Griffiths, 2013). In some sense, it is a dysfunctional tradeoff between increasing control over work and losing it over every other aspect of life, similar to one observed (for example) in anorexia nervosa. This could be reflected in unsuccessful attempts at reducing the behavior. However, it needs to be taken into account that addiction is strongly linked to denial and most of those who need intervention never recognize this fact or do not try to reduce the behavior (Goldstein et al., 2009).

Moreover, there are clear cases of death due to overwork, and the analysis of circumstances leading to such fatalities shows not only lack of effort to reduce work but also special actions to increase the amount of work. For example, there are cases of Polish medical doctors who die during hospital duty, typically after more than $24 \mathrm{hr}$ of continuous work. In order to be able to work so much, they have to establish their own business and work as an external contractor to circumvent work regulations (Ogólnopolski Związek Zawodowy Lekarzy, 2017). There are likely factors related to the disadvantageous medical policies, working environment, and/or limited number of physicians that contribute to this situation. However, finally, an individual needs to make consecutive decisions leading to an undue high amount of work and eventually to death (despite knowledge of physiological consequences of extreme stress and fatigue). While substance use disorders are well-known and persistent problems among physicians - often developed in response to paramount stress and responsibility (Domino et al., 2005) - there is very little known on how vulnerable individuals may react to demanding and unfavorable working conditions by developing work addiction. What is acknowledged though, by Doctors' Trade Union of Poland (Ogólnopolski Związek Zawodowy Lekarzy, 2017) and the Japanese Ministry of Health, Labour and Welfare, is that physicians die due to long working hours (Hiyama \& Yoshihara, 2008; Uehata, 2005). However, there is a distinction between working too hard because the individual feels that is what the job demands and being addicted to work (which will have completely different motivations).

Future studies would be likely to provide more insight into the motivational determinants of overloading oneself with work. More specifically, motives that distinguish healthy engagement and passion from unhealthy compulsion should be investigated (Andreassen, Ursin, \& Eriksen, 2007; Burke \& Fiskenbaum, 2009; Griffiths, 2011; Sussman, 2018; Vallerand, 2015; Van den Broeck et al., 2011), as well as those concerning situational factors that may burden individuals with excessive workload and responsibility, and in which cases the excessive work might have little to do with addiction. One such example concerns the motivations characterizing workers who give in to the excessive demands of work during an economic crisis (Kondo \& Oh, 2010). Arguably, in many cases, these motivations are rooted in the basic human physical and safety needs and have nothing to do with addiction but could be just as disruptive and/or destructive in an individual's health status (e.g., effects of stress) and social relationships (e.g., impact on family interactions).
Withdrawal symptoms are generally understudied in behavioral addictions (Kaptsis, King, Delfabbro, \& Gradisar, 2016). Most often they are described in terms of irritability and restlessness following cessation of the activity. In the case of work addiction, there is fairly strong indication of the possibility of existence of some kind of physical withdrawal. For example, there is a line of research on the so-called "leisure sickness." It is observed that some people feel ill and develop symptoms particularly during weekends and vacations (Van Heck \& Vingerhoets, 2007). Moreover, about $15 \%$ of participants in Poland (Atroszko, Pallesen, Griffiths, $\&$ Andreassen, 2017) and 12\% in Norway (nationally representative sample; Andreassen et al., 2014) indicated that they often or always become stressed if they are prohibited from working. Further studies are necessary to suggest specific criteria concerning withdrawal typical for work addiction. Nevertheless, these characteristic symptoms of withdrawal appear to be present in work addiction and are probably no less severe than those for caffeine withdrawal (APA, 2013). This issue requires more studies utilizing clinical populations to help delineate the psychobiological mechanisms of these responses, including the interplay between nervous, endocrinological, and immune systems. Special attention should also be devoted to controlling the confounding factors such as change of environment during non-working days (see Van Heck \& Vingerhoets, 2007).

It is suggested that congruent with the manner in which other addictions are conceptualized, and with understanding of the coping role of addiction/emotion regulation (Atroszko, 2015, 2018; Brevers \& Noel, 2015; Griffiths, 2017; Jacobs, 1986; Konkolÿ Thege, 2017; Kun \& Demetrovics, 2010; Marmet, Studer, Rougemont-Bücking, \& Gmel, 2018; Shaffer et al., 2004; Sinha, 2008; Sussman, Rozgonjuk, \& Van den Eijnden, 2017; Tunney \& James, 2017; Van der Linden, 2015), other comorbid or underlying psychological problems should not be viewed as exclusion criteria for work addiction. To date, other co-occurring disorders found in work addiction studies include attentiondeficit hyperactivity disorder, obsessive-compulsive disorder, major depressive disorder, and generalized anxiety disorder (Andreassen, Griffiths, Sinha, Hetland, \& Pallesen, 2016; Atroszko et al., 2017). Furthermore, taking into account the similarities between some of the symptoms of work addiction and obsessive-compulsive personality disorder (OCPD), the relationship between these constructs needs further clarification (see Atroszko, 2018; Loscalzo \& Giannini, 2018a, 2018b). Given that the results of the OCPD studies are often inconsistent and there are few wellestablished facts regarding this diagnosis (Diedrich \& Voderholzer, 2015), perhaps research concerning work addiction could shed more insight on OCPD itself, including its potential reevaluation.

It is argued that the harm produced by work addiction should include, apart from family and coworkers, other individuals who may suffer consequences of work addicts' actions attributable to the work addiction itself. For example, there is the increasing problem of burnout among medical doctors in the US and many other countries (Imo, 2017; Panagioti et al., 2017; Shanafelt et al., 2015; West, Dyrbye, Erwin, \& Shanafelt, 2016) as well as affecting medical students and residents (Dyrbye \& Shanafelt, 2016). 
Burnout increases risk of medical errors (Tawfik et al., 2018), and has been associated with work addiction in previous studies (Griffiths et al., 2018). At present, there is no estimate of how many medical errors are directly attributable to work addiction. Arguably, such harm and distress to the recipients of professional work could affect any other vocation from kindergarten teachers to policymakers.

We hope that our suggested definition of work addiction can facilitate collaborative development of the diagnostic criteria for work addiction and their validation. A proper differentiation between mild, moderate, and severe work addiction based on the number of met criteria could be one of the challenges. Apart from properly operationalized common addiction components (Andreassen, Griffiths, Hetland, \& Pallesen, 2012; Griffiths, 2005), the criteria would also need to consider such factors as the enjoyment/satisfaction from work, involvement in work, self-efficacy in work, socioeconomic status, and financial situation (i.e., significant socioeconomic repercussions as a consequence of reducing the number of hours worked), severity of harm, harm to oneself and/or harm to others, and self-awareness of the problem.

\section{THE NEED FOR A TRANSDISCIPLINARY AND INTEGRATIVE APPROACH TO RESEARCH CONCERNING WORK ADDICTION}

The published commentaries generally agreed that work addiction is not solely the result of individual personality factors (Myth 5) and they strongly suggested more transdisciplinary and integrative approach in research including micro-, meso-, and macro-level factors contributing to work addiction (Andreassen et al., 2018; Kun, 2018; Lior et al., 2018; Loscalzo \& Giannini, 2018a; Malinowska, 2018; Quinones, 2018; Sussman, 2018; Tóth-Király et al., 2018). To date, a substantial proportion of published studies have focused on the micro-level individual characteristics related to work addiction, such as personality traits (rigid perfectionism, neuroticism, conscientiousness, narcissism, self-esteem, etc.; Griffiths et al., 2018). There are broadly investigated models of organizational stressors such as demand-control-support model (Bakker \& Demerouti, 2007) or job demands resources model (Demerouti, Bakker, Nachreiner, \& Schaufeli, 2001) that are used to help explain and understand work addiction.

However, although there are some data from organizational and work psychology that contributes to the understanding of meso-level factors concerning work addiction and their interactions with micro-level factors (e.g., working environment, organizational culture, etc.; Andreassen et al., 2017), there are almost no studies on macro-level factors. A few sources of data, for example, on cultural factors related to work addiction (Hu et al., 2014) or on the increase of karoshi and karojisatsu during economic crisis (Kondo \& Oh, 2010) briefly touch upon the problem. Nevertheless, this is the most underdeveloped level of analysis and arguably the most crucial. It is wellestablished epidemiologically that the prevalence of a disease or disorder in population has relationships with the average level of specific behaviors within the population (Rose, 2001), such as the number of individuals abusing alcohol is related to the mean consumption of alcohol in the population. Therefore, it can be expected that the number of work addicts can be predicted on the basis of mean time spent on work or the mean level of work engagement in a particular society. From this premise, it follows that it is fundamental to understand factors influencing work culture in a particular population, as well as its interaction with micro- and meso-level factors.

\section{THE NEED FOR HIGH-QUALITY RESEARCH}

Finally, most of the commentaries emphasized the need to improve the quality of research, and some identified the still relatively low quality of research as the main obstacle in the development of work addiction field. Although there were 1,460 results on Google Scholar in 2017 based on the search terms "work addiction" or "workaholism," there were only 44 results indexed in the Web of Science during the same period. This suggests significant disproportion between how many papers on work addiction are published in general and how many are published in impactful scientific journals. Another facet of the problem is that many studies are published in languages other than English, and these are not always integrating the scientific knowledge and high level of methodology available internationally.

The recommendations from the commentaries include a need for more: (a) longitudinal studies; (b) studies about family members of work-addicted people; (c) studies on cognitive, neurobiological, and genetic correlates to work addiction; (d) studies on interactions between micro-, meso-, and macro-level factors contributing to work addiction; (e) use of registry-based studies; (f) observational studies of behavior/responses of work addicts; (g) experimental studies investigating, for example, withdrawal effects, cognitive bias, and treatment effects among work addicts; (h) studies using $360^{\circ}$ employee ratings of work addicts as well as studies incorporating collateral (e.g., spouse) ratings; and (i) studies on estimation of the prevalence of work addiction in different working populations (e.g., medical doctors, lawyers, managers, teachers, researchers, IT professionals, etc.), which could help to identify populations atrisk of work addiction.

\section{THE PLEA FOR INCLUSIVE COLLABORATIVE EFFORT}

Work addiction is a complex problem that cannot be understood and dealt without extensive collaboration, goodwill, and joint efforts from experts in a variety of fields and disciplines. There is still strong resistance from some quarters to acknowledge that work addiction can cause significant harm, which is directly expressed (Kardefelt-Winther et al., 2017) and is continuously emphasized by some of the members of the addiction research community (Atroszko, 2019; Starcevic et al., 2018). The unwillingness to recognize work addiction as a major problem probably reflects the fact that in most industrialized societies, work is one of the most 
(if not the most) valued activities and basis for strong personal identity. However, it could also be asked "what is the real cost and meaning of this activity?" Work addiction has been consistently associated with higher levels of stress inside and outside of the work environment, as well as with depression and burnout (Griffiths et al., 2018). Chronic stress is a well-recognized risk factor for a multitude of disorders and non-communicable diseases (Cohen, JanickiDeverts, \& Miller, 2007), including depression.

Recently, it was estimated that the cost of depression related to stress at work in the European Union is $€ 617$ billion annually (Atroszko, 2018, 2019; European Agency for Safety and Health at Work, 2014). This is more than the gross domestic product of most European countries (International Monetary Fund, 2017), and that simply relates to depression. Depression, anxiety, and non-communicable diseases such as cardiovascular disease or diabetes are among leading causes of the global burden of disease (Vos et al., 2016), and their costs related to work stress are nontrivial (European Agency for Safety and Health at Work, 2014). Studies examining prevalence of work addiction fairly consistently show that around $8 \%-10 \%$ could be affected, although this depends upon both the occupation and the instrument used to assess work addiction in the first place (Griffiths et al., 2018; Sussman, Lisha, \& Griffiths, 2011). At present, we do not know what proportion of the enormous costs of chronic stress inside and outside of work environments is directly attributed to work addiction. Nonetheless, it appears that there are sufficient empirical and theoretical premises to take a closer look at the association between work addiction and global burden of disease, and this is a challenge that no single researcher can undertake without extensive collaboration.

\section{CONCLUSIONS}

The commentaries agree that the field should go beyond the myths about work addiction. Significant challenges lay ahead as there is an urgent need to develop consensus regarding the definition of work addiction, systematic integration of data, and collaboration among researchers representing different areas of expertise, including specialists from fields such as medicine, psychology, economics, education, sociology, and others. Trajectories for future studies on a problematic work and work addiction have been delineated and hopefully this debate will contribute to the organization of a broader, but more integrated network of work addiction research.

Funding sources: This study was supported by the Hungarian National Research, Development and Innovation Office (grant numbers: K111938 and KKP126835).

Authors' contribution: All authors contributed to the preparation of this manuscript.

Conflict of interest: The authors declare no conflict of interest.

\section{REFERENCES}

American Psychiatric Association [APA]. (2013). Diagnostic and statistical manual of mental disorders (5th ed.). Arlington, VA: American Psychiatric Association.

Andreassen, C. S. (2014). Workaholism: An overview and current status of the research. Journal of Behavioral Addictions, 3(1), 1-11. doi:10.1556/JBA.2.2013.017

Andreassen, C. S., Bakker, A. B., Bjorvatn, B., Moen, B. E., Magerøy, N., Shimazu, A., Hetland, J., \& Pallesen, S. (2017). Working conditions and individual differences are weakly associated with workaholism: A 2-3-year prospective study of shift-working nurses. Frontiers in Psychology, 8, 2045. doi:10.3389/fpsyg.2017.02045

Andreassen, C. S., Griffiths, M. D., Hetland, J., Kravina, L., Jensen, F., \& Pallesen, S. (2014). The prevalence of workaholism: A survey study in a nationally representative sample of Norwegian employees. PLoS One, 9(8), e102446. doi:10.1371/ journal.pone. 0102446

Andreassen, C. S., Griffiths, M. D., Hetland, J., \& Pallesen, S. (2012). Development of a Work Addiction Scale. Scandinavian Journal of Psychology, 53(3), 265-272. doi:10.1111/ j.1467-9450.2012.00947.x

Andreassen, C. S., Griffiths, M. D., Sinha, R., Hetland, J., \& Pallesen, S. (2016). The relationships between workaholism and symptoms of psychiatric disorders: A large-scale crosssectional study. PLoS One, 11(5), e015297. doi:10.1371/ journal.pone. 0152978

Andreassen, C. S., \& Pallesen, S. (2016). Workaholism: An addiction to work. In V. R. Preedy (Ed.), Neuropathology of drug addictions and substance misuse (Vol. 3, pp. 972-983). London, UK: Academic Press.

Andreassen, C. S., Schaufeli, W. B., \& Pallesen, S. (2018). Myths about "The myths about work addiction": Commentary on: Ten myths about work addiction (Griffiths et al., 2018). Journal of Behavioral Addictions, 7(4), 858-862. doi:10.1556/2006.7. 2018.126

Andreassen, C. S., Ursin, H., \& Eriksen, H. R. (2007). The relationship between strong motivation to work, "workaholism", and health. Psychology and Health, 22(5), 615-629. doi:10.1080/14768320600941814

Atroszko, P. A. (2015). The structure of study addiction: Selected risk factors and the relationship with stress, stress coping and psychosocial functioning (Unpublished doctoral thesis). University of Gdańsk, Gdańsk, Poland.

Atroszko, P. A. (2018). Commentary on: The Bergen Study Addiction Scale: Psychometric properties of the Italian version. A pilot study. Theoretical and methodological issues in the research on study addiction with relevance to the debate on conceptualising behavioural addictions. Psychiatria i Psychologia Kliniczna, 18(3), 276-282. doi:10.15557/PiPK.2018.0034

Atroszko, P. A. (2019). Work addiction as a behavioural addiction: Towards a valid identification of problematic behaviour. Australian \& New Zealand Journal of Psychiatry. Advance online publication. 1-2. doi:10.1177/0004867419828496

Atroszko, P. A., Andreassen, C. S., Griffiths, M. D., \& Pallesen, S. (2015). Study addiction - A new area of psychological study: Conceptualization, assessment, and preliminary empirical findings. Journal of Behavioral Addictions, 4(2), 75-84. doi:10. 1556/2006.4.2015.007 
Atroszko, P. A., Andreassen, C. S., Griffiths, M. D., \& Pallesen, S. (2016a). Study addiction: A cross-cultural longitudinal study examining temporal stability and predictors of its changes. Journal of Behavioral Addictions, 5(2), 357-362. doi:10.1556/ 2006.5.2016.024

Atroszko, P. A., Andreassen, C. S., Griffiths, M. D., \& Pallesen, S. (2016b). The relationship between study addiction and work addiction: A cross-cultural longitudinal study. Journal of Behavioral Addictions, 5(4), 708-714. doi:10.1556/2006.5. 2016.076

Atroszko, P. A., Pallesen, S., Griffiths, M. D., \& Andreassen, C. S. (2017). Work addiction in Poland: Adaptation of the Bergen Work Addiction Scale and relationship with psychopathology. Health Psychology Report, 4(4), 345-355. doi:10.5114/hpr. 2017.68759

Bakker, A. B., \& Demerouti, E. (2007). The job demandsresources model: State of the art Journal of Managerial Psychology, 22, 309-328. doi:10.1108/02683940710733115

Babor, T. F., \& Caetano, R. (2008). The trouble with alcohol abuse: What are we trying to measure, diagnose, count and prevent? Addiction, 103(7), 1057-1059. doi:10.1111/j.13600443.2008.02263.x

Brevers, D., \& Noel, X. (2015). Commentary on: Are we overpathologizing everyday life? A tenable blueprint for behavioral addiction research: On functional and compulsive aspects of reinforcement pathologies. Journal of Behavioral Addictions, 4(3), 135-138. doi:10.1556/2006.4.2015.017

Burke, R. J., \& Fiksenbaum, L. (2009). Work motivations, work outcomes, and health: Passion versus addiction. Journal of Business Ethics, 84, 257-263. doi:10.1007/s10551-008-9697-0

Clark, M. A., Michel, J.S., Zhdanova, L., Pui, S. Y., \& Baltes, B. B. (2016). All work and no play? A meta-analytic examination of the correlates and outcomes of workaholism. Journal of Management, 42(7), 1836-1873. doi:10.1177/0149206314522301

Cohen, S., Janicki-Deverts, D., \& Miller, G. E. (2007). Psychological stress and disease. JAMA, 298(14), 1685-1687. doi:10.1001/jama.298.14.1685

Demerouti, E., Bakker, A. B., Nachreiner, F., \& Schaufeli, W. B. (2001). The job demands-resources model of burnout. Journal of Applied Psychology, 86(3), 499-512. doi:10.1037/00219010.86.3.499

Diedrich, A., \& Voderholzer, U. (2015). Obsessive-compulsive personality disorder: A current review. Current Psychiatry Reports, 17(2), 2. doi:10.1007/s11920-014-0547-8

Domino, K. B., Hornbein, T. F., Polissar, N. L., Renner, G., Johnson, J., Alberti, S., \& Hankes, L. (2005). Risk factors for relapse in health care professionals with substance use disorders. JAMA, 293(12), 1453-1460. doi:10.1001/jama.293. 12.1453

Dyrbye, L., \& Shanafelt, T. (2016). A narrative review on burnout experienced by medical students and residents. Medical Education, 50(1), 132-149. doi:10.1111/medu.12927

European Agency for Safety and Health at Work. (2014). Calculating the cost of work-related stress and psychosocial risks. European Risk Observatory Literature Review. Retrieved February 11, 2019, from https://osha.europa.eu/pl/tools-andpublications/publications/literature_reviews/calculating-the-costof-work-related-stress-and-psychosocial-risks

Everitt, B. J., \& Robbins, T. W. (2005). Neural systems of reinforcement for drug addiction: From actions to habits to compulsion. Nature Neuroscience, 8(11), 1481-1489. doi:10.1038/nn1579

Fassel, D. (1992). Working ourselves to death: The high costs of workaholism and the rewards of recovery. London, UK: Thorsons.

Goldstein, R. Z., Bechara, A., Garavan, H., Childress, A. R., Paulus, M. P., \& Volkow, N. D. (2009). The neurocircuitry of impaired insight in drug addiction. Trends in Cognitive Sciences, 13(9), 372-380. doi:10.1016/j.tics.2009.06.004

Grant, J. E., Potenza, M. N., Weinstein, A., \& Gorelick, D. A. (2010). Introduction to behavioral addictions. American Journal of Drug and Alcohol Abuse, 36(5), 233-241. doi:10.3109/ 00952990.2010 .491884

Griffiths, M. D. (1996). Behavioural addictions: An issue for everybody? Journal of Workplace Learning, 8(3), 19-25. doi:10.1108/13665629610116872

Griffiths, M. D. (2005). A 'components' model of addiction within a biopsychosocial framework. Journal of Substance Use, 10(4), 191-197. doi:10.1080/14659890500114359

Griffiths, M. D. (2011). Workaholism: A 21st century addiction. The Psychologist: Bulletin of the British Psychological Society, 24, 740-744.

Griffiths, M. D. (2013). Is "loss of control" always a consequence of addiction? Frontiers in Psychiatry, 4, 36. doi:10.3389/ fpsyt.2013.00036

Griffiths, M. D. (2017). Behavioural addiction and substance addiction should be defined by their similarities not their dissimilarities. Addiction, 112(10), 1718-1720. doi:10.1111/ add. 13828

Griffiths, M. D., Demetrovics, Z., \& Atroszko, P. A. (2018). Ten myths about work addiction. Journal of Behavioral Addictions, 7(4), 845-857. doi:10.1556/2006.7.2018.05

Griffiths, M. D., \& Karanika-Murray, M. (2012). Contextualising over-engagement in work: Towards a more global understanding of workaholism as an addiction. Journal of Behavioral Addictions, 1(3), 87-95. doi:10.1556/JBA.1.2012.002

Hasin, D. S. (2012). Combining abuse and dependence in DSM-5. Journal of Studies on Alcohol and Drugs, 73(4), 702-704. doi:10.15288/jsad.2012.73.702

Hiyama, T., \& Yoshihara, M. (2008). New occupational threats to Japanese physicians: Karoshi (death due to overwork) and karojisatsu (suicide due to overwork). Occupational and Environmental Medicine, 65(6), 428-429. doi:10.1136/oem. 2007.037473

Holden, C. (2001). 'Behavioral' addictions: Do they exist? Science, 294(5544), 980-982. doi:10.1126/science.294.5544.980

Hu, Q., Schaufeli, W., Taris, T. W., Hessen, D. J., Hakanen, J., Salanova, M., \& Shimazu, A. (2014). "East is east and west is west and never the twain shall meet:" Work engagement and workaholism across Eastern and Western cultures. Procedia: Social and Behavioral Sciences, 1, 6-24. Retrieved from https://www.wilmarschaufeli.nl/publications/Schaufeli/ 427.pdf

Imo, U. O. (2017). Burnout and psychiatric morbidity among doctors in the UK: A systematic literature review of prevalence and associated factors. BJPsych Bulletin, 41(4), 197-204. doi:10.1192/pb.bp.116.054247

International Monetary Fund. (2017). World Economic Outlook 2017. Retrieved February 11, 2018, from https://www.imf.org/ external/pubs/ft/weo/2017/02/weodata/WEOOct2017all.xls 
Jacobs, D. F. (1986). A general theory of addictions: A new theoretical model. Journal of Gambling Behavior, 2(1), 15-31. doi:10.1007/BF01019931

Kaptsis, D., King, D. L., Delfabbro, P. H., \& Gradisar, M. (2016). Withdrawal symptoms in Internet gaming disorder: A systematic review. Clinical Psychology Review, 43, 58-66. doi:10.1016/j.cpr.2015.11.006

Karanika-Murray, M., Duncan, N., Pontes, H., \& Griffiths, M. D. (2015). I belong therefore I am: An empirical investigation of work engagement, organizational identification and job satisfaction. Journal of Managerial Psychology, 30(8), 1019-1033. doi:10.1108/JMP-11-2013-0359

Kardefelt-Winther, D., Heeren, A., Schimmenti, A., Rooij, A., Maurage, P., Carras, M., \& Billieux, J. (2017). How can we conceptualize behavioural addiction without pathologizing common behaviours? Addiction, 112, 1709-1715. Retrieved from http://www.uclep.be/wp-content/uploads/pdf/Pub/Kardefelt_ Addiction_2017.pdf

Kondo, N., \& Oh, J. (2010). Suicide and karoshi (death from overwork) during the recent economic crises in Japan: The impacts, mechanisms and political responses. Journal of Epidemiology and Community Health, 64(8), 649-650. doi:10.1136/jech.2009.090787

Konkolÿ Thege, B. (2017). The coping function of mental disorder symptoms: Is it to be considered when developing diagnostic criteria for behavioural addictions? Addiction, 112(10), 1716-1717. doi:10.1111/add.13816

Koob, G. F., \& Volkow, N. D. (2010). Neurocircuitry of addiction. Neuropsychopharmacology, 35(1), 217-238. doi:10.1038/npp. 2009.110

Kun, B. (2018). Ten myths and twenty years: What we know and what we still do not know about work addiction: Commentary on: Ten myths about work addiction (Griffiths et al., 2018). Journal of Behavioral Addictions, 7(4), 863-866. doi:10.1556/ 2006.7.2018.125

Kun, B., \& Demetrovics, Z. (2010). Emotional intelligence and addictions: A systematic review. Substance Use \& Misuse, 45(7-8), 1131-1160. doi:10.3109/10826080903567855

Lior, O., Abira, R., \& Aviv, W. (2018). Work addiction: An organizational behavior as well as an addictive behavior?: Commentary on: Ten myths about work addiction (Griffiths et al., 2018). Journal of Behavioral Addictions, 7(4), 888-891. doi:10.1556/2006.7.2018.119

Loscalzo, Y., \& Giannini, M. (2018a). Problematic overstudying: Studyholism or study addiction?: Commentary on: Ten myths about work addiction (Griffiths et al., 2018). Journal of Behavioral Addictions, 7(4), 867-870. doi:10.1556/2006.7. 2018.124

Loscalzo, Y., \& Giannini, M. (2018b). Response to: Theoretical and methodological issues in the research on study addiction with relevance to the debate on conceptualising behavioural addictions: Atroszko (2018). Psychiatria i Psychologia Kliniczna, 18(4), 426-430. doi:10.15557/PiPK.2018.0051

Malinowska, D. (2018). How to counter the ten myths about work addiction?: Three postulates for future research: Commentary on: Ten myths about work addiction (Griffiths et al., 2018). Journal of Behavioral Addictions, 7(4), 871-874. doi:10.1556/ 2006.7.2018.123

Marmet, S., Studer, J., Rougemont-Bücking, A., \& Gmel, G. (2018). Latent profiles of family background, personality and mental health factors and their association with behavioural addictions and substance use disorders in young Swiss men. European Psychiatry, 52, 76-84. doi:10.1016/j.eurpsy.2018. 04.003

Oates, W. E. (1971). Confessions of a workaholic. New York, NY: World Books.

O'Brien, C. (2011). Addiction and dependence in DSM-V. Addiction, 106, 866-867.

Ogólnopolski Związek Zawodowy Lekarzy. (2017). Oświadczenie OZZL $w$ sprawie kolejnych przypadków śmierci lekarzy na dy urach [Doctors' Trade Union of Poland]. Retrieved February 11, 2018, from http://www.ozzl.org.pl/index.php/ 13720-oswiadczenie-ozzl-w-sprawie-kolejnych-przypadkowsmierci-lekarzy-na-dyzurach

Quinones, C. (2018). Moving from the terminology debate to a transdisciplinary understanding of the problem: Commentary on: Ten myths about work addiction (Griffiths et al., 2018). Journal of Behavioral Addictions, 7(4), 880-883. doi:10.1556/ 2006.7.2018.121

Quinones, C., \& Griffiths, M. D. (2015). Addiction to work: A critical review of the workaholism construct and recommendations for assessment. Journal of Psychosocial Nursing and Mental Health Services, 53(10), 48-59. doi:10.3928/ 02793695-20150923-04

Panagioti, M., Panagopoulou, E., Bower, P., Lewith, G., Kontopantelis, E., Chew-Graham, C., Dawson, S., van Marwijk, H., Geraghty, K., \& Esmail, A. (2017). Controlled interventions to reduce burnout in physicians: A systematic review and meta-analysis. JAMA Internal Medicine, 177(2), 195-205. doi:10.1001/jamainternmed.2016.7674

Robinson, B. E. (2014). Chained to the desk: A guidebook for workaholics, their partners and children, and the clinicians who treat them. New York, NY: NYU Press.

Rose, G. (2001). Sick individuals and sick populations. International Journal of Epidemiology, 30(3), 427-432. doi:10.1093/ ije/30.3.427

Schaufeli, W. B., Taris, T. W., \& Bakker, A. B. (2006). Doctor Jekyll or Mr Hyde? On the differences between work engagement and workaholism. In R. Burke (Ed.), Research companion to working time and work addiction (pp. 193-217). Cheltenham, UK: Edward Elgar.

Shaffer, H. J., LaPlante, D. A., LaBrie, R. A., Kidman, R. C., Donato, A. N., \& Stanton, M. V. (2004). Toward a syndrome model of addiction: Multiple expressions, common etiology. Harvard Review of Psychiatry, 12(6), 367-374. doi:10.1080/ 10673220490905705

Shanafelt, T. D., Hasan, O., Dyrbye, L. N., Sinsky, C., Satele, D., Sloan, J., \& West, C. P. (2015). Changes in burnout and satisfaction with work-life balance in physicians and the general US working population between 2011 and 2014. Mayo Clinic Proceedings, 90(12), 1600-1613. doi:10.1016/j. mayocp.2015.08.023

Sinha, R. (2008). Chronic stress, drug use, and vulnerability to addiction. Annals of the New York Academy of Sciences, 1141(1), 105-130. doi:10.1196/annals.1441.030

Snir, R., \& Harpaz, I. (2012). Beyond workaholism: Towards a general model of heavy work investment. Human Resource Management Review, 22(3), 232-243. doi:10.1016/j.hrmr. 2011.11.011

Snir, R., \& Zohar, D. (2008). Workaholism as discretionary time investment at work: An experience-sampling study. Applied Psychology, 57(1), 109-127. doi:10.1111/j.1464-0597.2006.00270.x 
Spence, J. T., \& Robbins, A. S. (1992). Workaholism: Definition, measurement, and preliminary results. Journal of Personality Assessment, 58(1), 160-178. doi:10.1207/s15327752jpa5801_15

Starcevic, V., Billieux, J., \& Schimmenti, A. (2018). Selfitis and behavioural addiction: A plea for terminological and conceptual rigour. Australian \& New Zealand Journal of Psychiatry, 52(10), 919-920. doi:10.1177/0004867418797442

Sussman, S. (2012). Workaholism: A review. Journal of Addiction Research \& Therapy, Suppl. 6(1), 4120. doi:10.4172/21556105.S6-001

Sussman, S. (2018). Ten myths (or facts?) about workaholism: An appetitive motivation framework: Commentary on: Ten myths about work addiction (Griffiths et al., 2018). Journal of Behavioral Addictions, 7(4), 884-887. doi:10.1556/2006. 7.2018 .120

Sussman, S., Lisha, N., \& Griffiths, M. (2011). Prevalence of the addictions: A problem of the majority or the minority? Evaluations \& the Health Professions, 34(1), 3-56. doi:10. 1177/0163278710380124

Sussman, S., Rozgonjuk, D., \& Van den Eijnden, R. J. (2017). Substance and behavioral addictions may share a similar underlying process of dysregulation. Addiction, 112(10), 1717-1718. doi:10.1111/add.13825

Sussman, S., \& Sussman, A. N. (2011). Considering the definition of addiction. International Journal of Environmental Research and Public Health, 8(10), 4025-4038. doi:10.3390/ijerph8104025

Taris, T. W., Schaufeli, W. B., \& Verhoeven, L. C. (2005). Workaholism in the Netherlands: Measurement and implications for job strain and work-nonwork conflict. Applied Psychology, 54(1), 37-60. doi:10.1111/j.1464-0597.2005.00195.x

Tawfik, D. S., Profit, J., Morgenthaler, T. I., Satele, D. V., Sinsky, C. A., Dyrbye, L. N., Tutty, M. A., West, C. P., \& Shanafelt, T. D. (2018). Physician burnout, well-being, and work unit safety grades in relationship to reported medical errors. Mayo Clinic Proceedings, 93(11), 1571-1580. doi:10.1016/j. mayocp.2018.05.014

Tóth-Király, I., Bőthe, B., \& Orosz, G. (2018). Seeing the forest through different trees: A social psychological perspective of work addiction: Commentary on: Ten myths about work addiction (Griffiths et al., 2018). Journal of Behavioral Addictions, 7(4), 875-879. doi:10.1556/2006.7.2018.122

Tunney, R. J., \& James, R. J. (2017). Criteria for conceptualizing behavioural addiction should be informed by the underlying behavioural mechanism. Addiction, 112(10), 1720-1721. doi:10.1111/add.13831

Uehata, T. (2005). Karoshi, death by overwork. Nihon rinsho. Japanese Journal of Clinical Medicine, 63, 1249-1253.

Vallerand, R. J. (2015). The psychology of passion: A dualistic model. New York, NY: Oxford University Press.

Van den Broeck, A., Schreurs, B., De Witte, H., Vansteenkiste, M., Germeys, F., \& Schaufeli, W. (2011). Understanding workaholics' motivations: A self-determination perspective. Applied Psychology, 60(4), 600-621. doi:10.1111/j.1464-0597.2011. 00449.x

Van der Linden, M. (2015). Commentary on: Are we overpathologizing everyday life? A tenable blueprint for behavioral addiction research: Addictions as a psychosocial and cultural construction. Journal of Behavioral Addictions, 4(3), 145-147. doi:10.1556/2006.4.2015.025

Van Heck, G. L., \& Vingerhoets, A. J. (2007). Leisure sickness: A biopsychosocial perspective. Psychological Topics, 16, 187-200. Retrieved from https://hrcak.srce.hr/file/32013

Vos, T., Allen, C., Arora, M., Barber, R. M., Bhutta, Z. A., Brown, A., ... \& Coggeshall, M. (2016). Global, regional, and national incidence, prevalence, and years lived with disability for 310 diseases and injuries, 1990-2015: A systematic analysis for the Global Burden of Disease Study 2015. The Lancet, 388(10053), 1545-1602. doi:10.1016/S0140-6736(16)31678-6

Wakefield, J. C. (2015). DSM-5 substance use disorder: How conceptual missteps weakened the foundations of the addictive disorders field. Acta Psychiatrica Scandinavica, 132(5), 327-334. doi:10.1111/acps.12446

West, C. P., Dyrbye, L. N., Erwin, P. J., \& Shanafelt, T. D. (2016). Interventions to prevent and reduce physician burnout: A systematic review and meta-analysis. The Lancet, 388(10057), 2272-2281. doi:10.1016/S0140-6736(16)31279-X 